\title{
CLINICOPATHOLOGICAL CORRELATIONS OF NEUROENDOCRINE CELL HYPERPLASIA IN ULCERATIVE COLITIS PATIENTS
}

\author{
Anamaria CURTE ${ }^{1 凶}$, Catalina NICOLAE ${ }^{1}$, Madalina CHIVU ${ }^{1}$, Florin ANDREI ${ }^{1}$, \\ Cristian TIERANU ${ }^{2}$, Maria SAJIN ${ }^{3}$, Gabriel BECHEANU ${ }^{3}$ \\ ${ }^{1}$ Elias University Emergency Hospital, Pathology Department, Bucharest, Romania \\ ${ }^{2}$ Elias University Emergency Hospital, Gastroenterology Department, Bucharest, Romania \\ 3"Carol Davila" University of Medicine and Pharmacy, Bucharest, Romania
}

Received 16 Apr 2020, Accepted 15 May 2020

hitps://doi.org/10.31688/ABMU.2020.55.2.09

\section{Abstract}

Introduction. Several studies have shown that neuroendocrine cells (NECs) are increased in the colorectal mucosa of patients with ulcerative colitis (UC) compared to normal, mainly in the left colon. A threshold of 3.2 NECs/crypt has been proposed by some authors for defining NEC hyperplasia in these patients. However, correlations of NEC changes with clinical parameters have not been described.

The objective of this study was to analyze NEC histological changes, described by several descriptors, in UC patients and identify relevant clinicopathological correlations.

Material and methods. We analyzed colonic biopsies from 42 UC patients by highlighting the neuroendocrine cells with Chromogranin A immunohistochemical stain. Positive cells were detected and quantified by computerized image analysis, and their morphology and distribution were assessed. The data obtained were described as mean and maximum number of cells per crypt, and number of crypts showing linear hyperplasia.

\section{Résumé}

Corrélations cliniques et pathologiques de l'hyperplasie des cellules neuro-endocrines chez les patients atteints de colite ulcéreuse

Introduction. Plusieurs études ont montré que les cellules neuro-endocrines (CNE) sont accrues dans la muqueuse colorectale des patients atteints de colite ulcéreuse $(\mathrm{CU})$ par rapport à la normale, principalement dans le côlon gauche. Un seuil de 3,2 NEC / crypte a été proposé par certains auteurs pour définir l'hyperplasie CNE chez ces patients. Cependant, les corrélations des changements de $\mathrm{CNE}$ avec les paramètres cliniques n'ont pas été décrites.

L'objectif de cette étude était d'analyser les changements histologiques NEC, décrits par plusieurs décripteurs, chez les patients CU et d'identifier les corrélations clinico-pathologiques pertinentes.

Matériel et méthodes. Nous avons analysé les biopsies coliques de 42 patients avec $\mathrm{CU}$ en mettant en évidence les cellules neuro-endocrines avec une coloration immunohistochimique à la Chromogranine A.

$\triangle$ Address for correspondence:

Anamaria CURTE

Elias University Emergency Hospital, Bucharest, Romania

Address: Blvd. Marasti 17, Sector 1, 011461, Bucharest, Romania

E-mail: anma.pop@gmail.com; Phone +40743 040 852; Fax +4021 3161602 
Results. Increased numbers of cryptic NECs were identified (mean 3.62/crypt). A rising trend was observed for Nancy grades 2 and 3 and a small decrease for grade 4 at the site of most severely active inflammation. However, linear hyperplasia negatively correlated with increase of Nancy and Geboes grades of histological inflammation ( $\mathrm{rho}=-0.326, \mathrm{p}=0.013$; respectively rho $=0.368, \mathrm{p}=0.005)$ and with age $\left(r_{\mathrm{p}}=-0.328, \mathrm{p}=0.039\right)$. The maximum counts per crypt correlated positively with corticosteroid treatment $(r=0,332, p=0.012)$. The mean count per crypt negatively correlated with disease duration $(r=-0.388, p=0.013)$.

Conclusion. NEC hyperplastic changes correlate with important clinical and histological parameters and could impact on the management of UC patients.

Keywords: neuroendocrine cell hyperplasia, linear hyperplasia, ulcerative colitis, histological score of inflammation.

\section{List of abbreviations}

$\mathrm{NEC}=$ neuroendocrine cell

GS $=$ Geboes score

$\mathrm{NI}=$ Nancy index

$\mathrm{UC}=$ ulcerative colitis
Les cellules positives ont été détectées et quantifiées par l'analyse d'image informatisée, et leur morphologie et leur distribution ont été évaluées. Les données obtenues ont été décrites comme le nombre moyen et maximum de cellules par crypte et le nombre de cryptes montrant une hyperplasie linéaire.

Résultats. Un nombre accru de CNE cryptiques a été identifié (moyenne 3,62/crypte). Une tendance à la hausse a été observée pour les grades 2 et 3 de Nancy et une légère diminution pour le grade 4 au site de l'inflammation la plus sévèrement active. Cependant, l'hyperplasie linéaire était corrélée négativement avec l'augmentation des degrés d'inflammation histologique de Nancy et Geboes (rho=-0.326, $\mathrm{p}=0.013$; respectivement rho $=-0.368, p=0.005)$ et avec l'âge $\left(r_{p}=-0.328, p=0.039\right)$. Les comptes maximaux par crypte étaient en corrélation positive avec le traitement aux corticostéroïdes $\left(r_{\mathrm{p}}=0.332, \mathrm{p}=0.012\right)$. Le nombre moyen par crypte était corrélé négativement avec la durée de la maladie $(r=-0.388, \mathrm{p}=0.013)$.

Conclusion. Les changements hyperplasiques du CNE sont en corrélation aux paramètres cliniques et histologiques importants et pourraient avoir un impact sur la prise en charge des patients atteints de CU.

Mots-clés: hyperplasie des cellules neuro-endocrines, hyperplasie linéaire, colite ulcéreuse, score histologique d'inflammation.

research has evaluated the relation between NEC hyperplasia and severity of histological inflammation, nor has explored other NEC histological parameters to our knowledge.

Various histological descriptors of the patterns of NEC proliferation could better characterize the inflammation in these patients and become prognostic factors in UC patients.

The objective of the Study was to determine if the presence of NECs hyperplasia and distribution of CgA-positive cells correlate with the severity of inflammation, reflected in the histological score in patients with ulcerative colitis. We intended to assess whether correlations exist between NEC histological parameters and clinical features, e.g. age, duration of disease, Mayo endoscopic score, treatment received by the patients.

\section{Material AND Methods}

In this study, we retrospectively searched for patients with a diagnosis of ulcerative colitis in the last three years, from 2017 to 2019, in the Pathology department of Elias University Emergency Hospital, 
Table 1. Clinical and histopathological features of the patients

\begin{tabular}{|c|c|}
\hline Cases & 42 \\
\hline Gender & 17 Females, 25 Males \\
\hline Age & Mean 38.21years (18-70; median 47) \\
\hline Duration of disease & Mean 40 months (1-172) \\
\hline Treatment & Yes $-71.42 \%$, No $-28.57 \%$ \\
\hline Conventional therapy & $86.66 \%$ \\
\hline Biological therapy & $23.33 \%$ \\
\hline Endoscopy & \\
\hline Mayo partial score & Mayo score $\geq 2-90.47 \%$ of cases \\
\hline Montreal classification & $\mathrm{E} 1-11.9 \%, \mathrm{E} 2-35.71 \%, \mathrm{E} 3-52.38 \%$ \\
\hline Colonic segment of origin & Right colon $-10.51 \%$ \\
\hline & Left colon $-29.81 \%$ \\
\hline & Rectum $-24.56 \%$ \\
\hline & Not specified $-35.08 \%$ \\
\hline Histopathology & \\
\hline Inflammation score & \\
\hline Nancy Index & $\geq$ grade $3-78.94 \%$ \\
\hline Geboes grade & $\geq$ grade $3.2-85.96 \%$ \\
\hline $\mathrm{NEC}^{1}$ hyperplasia & \\
\hline Mean number of NECs/crypt & $3.62 \mathrm{NECs} / \mathrm{crypt}$ \\
\hline Mean number of NECs/crypt $\left(\right.$ hotspot $\left.^{2}\right)$ & 5.97 NECs/crypt \\
\hline Maximum number of NECs/crypt & $18.85 \mathrm{NECs} / \mathrm{crypt}$ \\
\hline Mean number of crypts with $\mathrm{LH}^{3}$ & 0.05 crypts/slide \\
\hline Mean number of crypts with LH in hotspot & 2.7 crypts/10 crypts \\
\hline \multicolumn{2}{|l|}{1 Neuroendocrine cell } \\
\hline \multirow{2}{*}{\multicolumn{2}{|c|}{2 Hotspot was defined as an area of 10 crypts with the most numerous Chromogranin A positive cells per crypt. }} \\
\hline & ive cells in a crypt \\
\hline \multicolumn{2}{|c|}{ Histological variables describing NEC hyperplasia are presented as means. } \\
\hline
\end{tabular}

Bucharest, Romania. The histological slides were stained with hematoxylin and eosin. The level of inflammation was assessed using the Nancy index ${ }^{17}$ and Geboes score ${ }^{18}$.

NECs were highlighted by immunohistochemistry, using Cell Marque Chromogranin A (LK2H10) mouse monoclonal antibody, dilution 1:100, and 3,3'-diaminobenzidine (DAB) chromogen, following the protocol for paraffin-embedded sections.

Image analysis

Image analysis was performed using QuPath software, version $0.2 .0-\mathrm{m} 4^{19}$. The crypts were manually annotated. For positive cell detection, stain separation was achieved by color deconvolution and intensity thresholds were optimized. DAB-positive cell segmentation was automatically recorded hierarchically as objects per annotation. The automatic positive cell detection was checked visually. Automatic cell measurements were also based on documentary evidence and the data obtained were processed.

CgA positive-cells descriptors

The mean and maximum number of $\mathrm{CgA}$ positive cells per crypt, and number of crypts showing linear hyperplasia were selected as descriptors for evaluation of neuroendocrine cells. Hyperplasia was designated if $\geq 3.2 \mathrm{CgA}$-positive cells per crypt were found, as defined in previous studies ${ }^{11,20}$. When 5 or more contiguous CgA-positive cells were detected, the feature was described as linear hyperplasia. A hotspot area was defined as 10 crypts with the maximum number of CgA-positive cells on a slide assessed visually. The location, distribution and morphology of the positive cells within the crypts were evaluated, along with the presence of $\mathrm{CgA}$ positive cells within the mucosal lamina propria.

Statistical analysis was done using IBM SPSS Statistics Version 20.0. Armonk, NY, USA. Correlation between continuous variables was assessed by Pearson's correlation coefficient. Correlation between continuous and ordinal variables was assessed by Spearman's rank correlation coefficient. Correlation between continuous and dichotomous variables was assessed by calculation of the point-biserial correlation coefficient.

\section{Results}

We identified 42 cases of colonic biopsies taken from patients with ulcerative colitis at first diagnosis or at follow-up presentation. The clinical, endoscopic and histological main characteristics of the patients are presented in Table 1. Most of the cases showed extensive lesions (E2 or E3 by Montreal classification) 
Table 2. Correlations between the histological descriptors of neuroendocrine cell hyperplasia

\begin{tabular}{|c|c|c|c|c|c|c|}
\hline & $\begin{array}{l}\text { Pearson's cor- } \\
\text { relation }\end{array}$ & Mean/crypt & $\begin{array}{c}\text { Mean/crypt in } \\
\text { hotspot }\end{array}$ & $\begin{array}{c}\text { Maximum/ } \\
\text { crypt }\end{array}$ & Mean LH & $\begin{array}{l}\text { Mean LH } \\
\text { in hotspot }\end{array}$ \\
\hline Mean/crypt & $\begin{array}{c}r_{\mathrm{p}} \\
\mathrm{p} \text { value } \\
\end{array}$ & 1 & $\begin{array}{l}0.756 \\
0.000 \\
\end{array}$ & $\begin{array}{l}0.728 \\
0.000 \\
\end{array}$ & $\begin{array}{l}0.649 \\
0.000 \\
\end{array}$ & $\begin{array}{l}0.533 \\
0.000 \\
\end{array}$ \\
\hline $\begin{array}{c}\text { Mean/crypt in } \\
\text { hotspot }\end{array}$ & $\begin{array}{c}r_{\mathrm{p}} \\
\text { p value }\end{array}$ & $\begin{array}{l}0.756 \\
0.000 \\
\end{array}$ & 1 & $\begin{array}{l}0.672 \\
0.000 \\
\end{array}$ & $\begin{array}{l}0.713 \\
0.000 \\
\end{array}$ & $\begin{array}{l}0.681 \\
0.000 \\
\end{array}$ \\
\hline $\begin{array}{c}\text { Maximum/ } \\
\text { crypt }\end{array}$ & $\begin{array}{c}r_{\mathrm{p}} \\
\mathrm{p} \text { value }\end{array}$ & $\begin{array}{l}0.728 \\
0.000 \\
\end{array}$ & $\begin{array}{l}0.672 \\
0.000 \\
\end{array}$ & 1 & $\begin{array}{l}0.429 \\
0.001 \\
\end{array}$ & $\begin{array}{l}0.533 \\
0.000 \\
\end{array}$ \\
\hline Mean LH & $\stackrel{\substack{r_{p} \\
\text { p value }}}{\text { val }}$ & $\begin{array}{l}0.649 \\
0.000 \\
\end{array}$ & $\begin{array}{l}0.713 \\
0.000 \\
\end{array}$ & $\begin{array}{l}0.429 \\
0.001 \\
\end{array}$ & 1 & $\begin{array}{l}0.776 \\
0.000\end{array}$ \\
\hline $\begin{array}{l}\text { Mean LH } \\
\text { in hotspot }\end{array}$ & $\underset{\substack{r_{p} \\
\text { p value }}}{r_{0}}$ & $\begin{array}{l}0.533 \\
0.000\end{array}$ & $\begin{array}{l}0.681 \\
0.000\end{array}$ & $\begin{array}{l}0.533 \\
0.000\end{array}$ & $\begin{array}{l}0.776 \\
0.000\end{array}$ & 1 \\
\hline
\end{tabular}

Correlation is significant at the 0.01 level (2-tailed).

Linear hyperplasia is defined as a number of $\geq 5$ contiguous Chromogranin A positive cells.

Data are presented as number of Chromogranin A positive cells per crypt.

Table 3. Correlation test with statistical significance between NEC descriptors and clinical and histological variables

\begin{tabular}{cccc}
\hline NEC descriptors & Clinical variable & Coefficient of correlation & $\mathrm{p}$ value \\
\hline Mean NECs per crypt & Disease duration & & 0.013 \\
Overall & & $r_{\mathrm{p}}=-0.388$ & 0.008 \\
Hotspot & & $r_{\mathrm{p}}=-0.416$ & 0,012 \\
\hline Maximum NECs per crypt & Corticosteroid therapy & $r_{\mathrm{p}}=0,332$ & 0.013 \\
\hline Linear hyperplasia & Histological score of inflammation & & 0.005 \\
& Nancy Index & rho $=-0.326$ & 0,039 \\
\hline
\end{tabular}

Statistical tests used: Pearson's test was for disease duration and age; point biserial test for corticosteroid therapy; Spearman's test for histological scores of inflammation.

and moderate or severe inflammation, as assessed by endoscopic and histological scoring systems.

Increased numbers of NECs were identified within the crypts of ulcerative colitis patients. A positive correlation between all the histological descriptors of NECs hyperplasia was detected by Pearson's test, $\mathrm{p} \leq 0.001$ (Table 2).

Statistically significant correlations between the increased NEC cells and clinical and histological variables in patients with ulcerative colitis are summarized in Table 3 and presented below.

\section{The location, distribution and morphology of positive cells}

The colonic biopsies showed increased counts of NECs within the crypts, as highlighted by Chromogranin A immunohistochemical stain. NECs were detected as scattered single cells or as multiple contiguous cells, which took the form of small nests within the base of the crypts.

The hyperplastic NECs were predominantly located in the lower half of the crypts, but were occasionally seen in the upper half, sometimes in a linear fashion, especially when their numbers were markedly increased. Single cells usually had the shapes displayed normally by NECs. However, when hyperplasia was marked, they frequently were larger and had abundant, granular cytoplasm, which strongly stained for $\mathrm{CgA}$ (Figures $1 \mathrm{~A}$ to $1 \mathrm{E}$ ).

Chromogranin positive cells were sporadically identified in the basal intercryptal lamina propria or within areas of basal lymphocytic infiltrates of the mucosa. A link to a crypt was usually readily identified on serial sections. Nonetheless, in one case we detected a neuroendocrine cell micronest in the basal lamina propria (Figure 1F).

\section{Age}

Linear hyperplasia of neuroendocrine cells negatively correlated with the age of the patients by Pearson's test, with $r_{\mathrm{p}}=-0.328, \mathrm{p}=0.039$.

\section{Disease duration}

Disease evolution over time influenced NEC counts. A moderate negative correlation between the mean number of NECs per crypt, both overall and in hotspot, and the disease duration was demostrated by Pearson's correlation test $r_{\mathrm{p}}=-0.388, \mathrm{p}=0.013$; and 


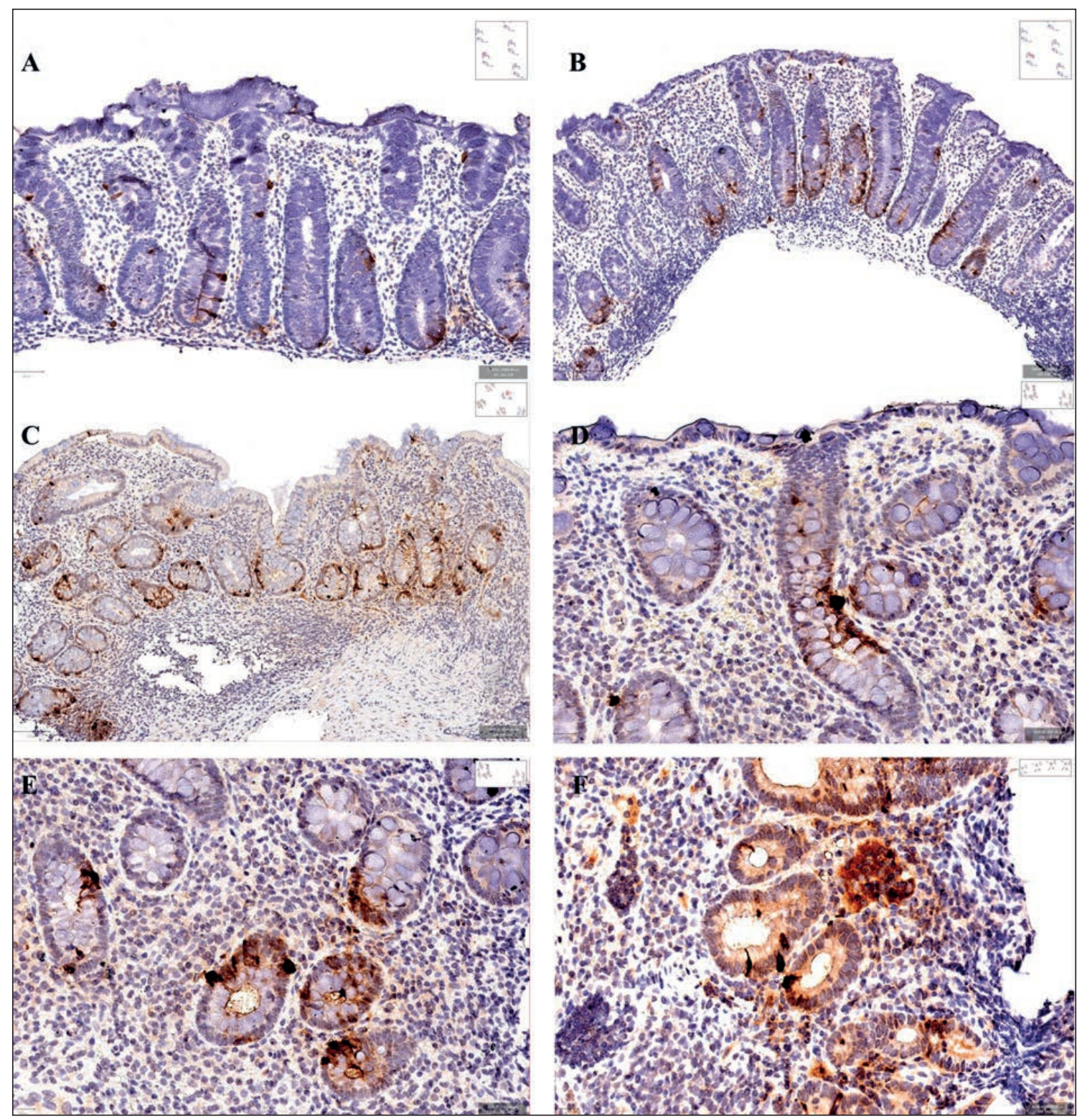

Figure 1. Chromogranin A immunohistochemical stain. (A) Normal crypt architecture and scattered normal neuroendocrine cells. A solitary neuroendocrine cell is seen in the basal lamina propria. (B) Neuroendocrine cell hyperplasia. Crypts are well oriented and focally shortened. (C) Diffuse neuroendocrine cell hyperplasia and markedly altered crypt architecture. (D) Altered crypt architecture. Linear hyperplasia in the upper half of a crypt.

(E) Neuroendocrine linear hyperplasia in colonic mucosa with altered crypt architecture. (F) A micro-nest of neuroendocrine cells in the superficial lamina propria of the ascending colon in a patient with pancolitis.

$r_{\mathrm{p}}=0.416, \mathrm{p}=0.008$ in hotspot). The decreasing trend of mean NECs per crypt over time is presented in Figure $2 \mathrm{~A}$. The mean numbers of crypts showing neuroendocrine linear hyperplasia follow the same pattern, but without statistically significant correlation (Figure 2B).

\section{Therapy}

Patients under corticosteroid therapy had significantly higher counts of maximum NEC per crypt than patients not receiving the medication (Figure 3), as shown by the point biserial statistical test $(r=0.332, \mathrm{p}=0.012)$. This result suggests that a high count of maximum NEC per crypt might predict the need for corticoid therapy in the future. This finding requires further investigation.

Patients under biological therapy did not show statistically significant changes in NEC descriptors of hyperplasia when compared to those not receiving immunotherapy. Still, neuroendocrine linear 

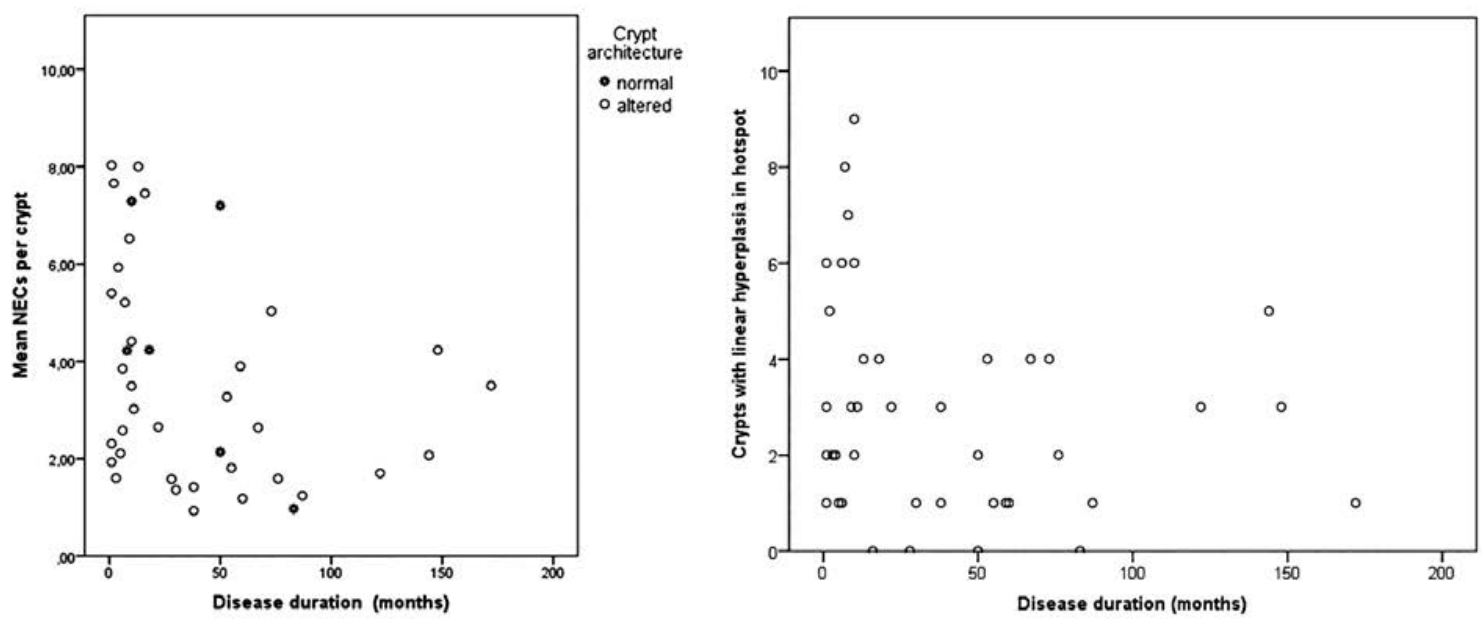

Figure 2. Correlation between the mean counts of neuroendocrine cells per crypt (A) and linear hyperplasia (B) and disease duration.

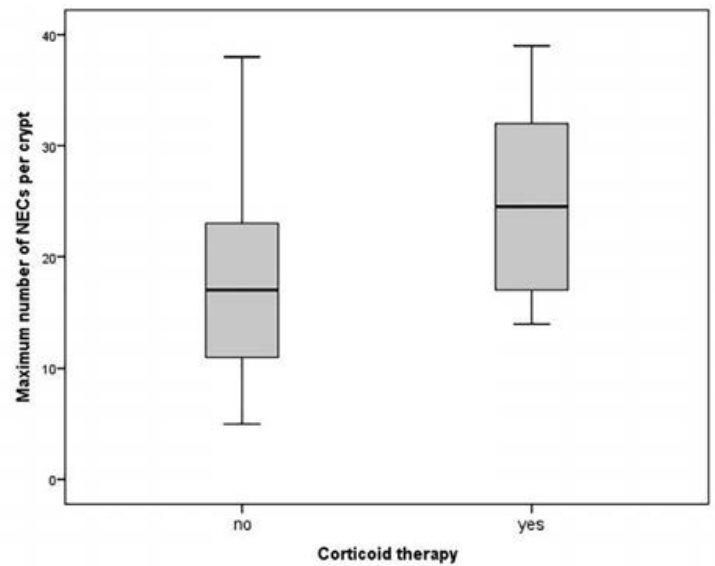

Figure 3. Correlation between the maximum numbers of neuroendocrine cells per crypt and corticosteroid therapy.

hyperplasia in the hotspot had a negative correlation coefficient $r_{\mathrm{p}}=0.244$, with a $\mathrm{p}$ value of 0.067 .

\section{Endoscopy}

The biopsies we analysed were taken by colonoscopists mainly from the left colon and rectum. However, for a significant proportion of the biopsies, the segment of origin was not specified, instead they were labelled by the colonoscopists as being sampled from the area most severely affected by disease, which is usually the sigmoid and/or the rectal segment. (Figure 4). Therefore, the association between NEC hyperplasia and the intestinal segment of origin could not be tested for statistical significance.

The endoscopic Mayo score did not correlate with the numbers of neuroendocrine cells in our sample.

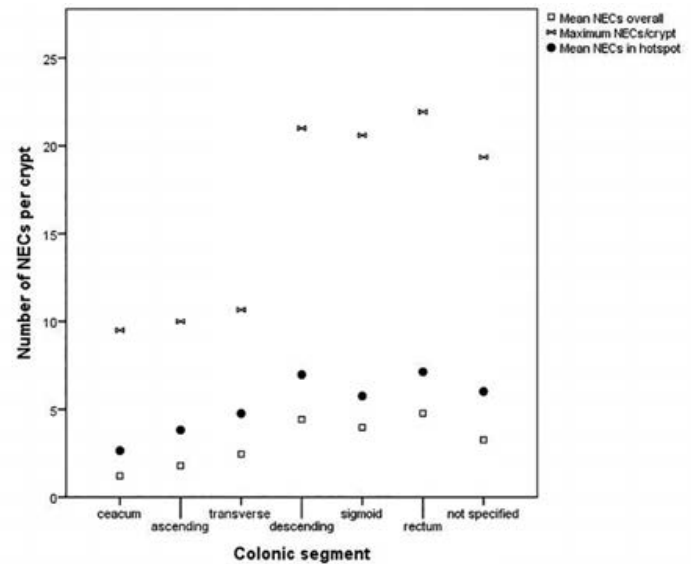

Figure 4. Mean and maximum counts of neuroendocrine cells per crypt according to the colonic segment.

\section{Histological inflammation}

There was a moderate negative correlation between the histological score of inflammation, for both Nancy index and Geboes score (Figures 5A and 5B), and the mean NEC linear hyperplasia, by Spearman's test $(\mathrm{rho}=-0.326, \mathrm{p}=0.013$ for NI; $\mathrm{rho}=-0.368, \mathrm{p}=0.005$ for GS). This finding could be explained by the fact that the biopsy fragments presented mostly acute injuries, in many cases in the form of granulation tissue.

NECs mean and maximum numbers seem to follow this trend but did not reach statistical significance in our sample.

Because of sampling mainly from the endoscopically injured area, no colonic biopsy showed a Nancy score of 0 or 1 , and a Geboes grade $<3.0$ respectively. Therefore, this study does not describe NEC 

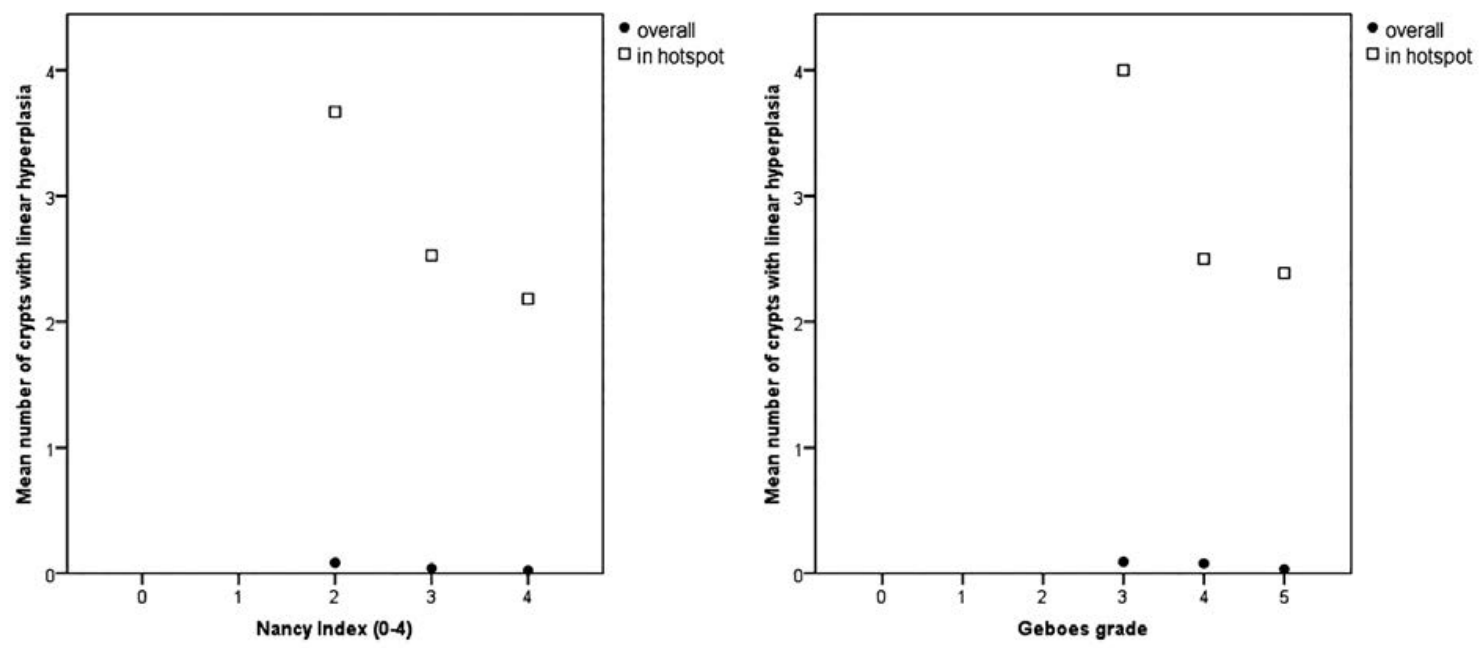

Figure 5. Mean number of crypts showing neuroendocrine linear hyperplasia according to Nancy index (A) and Geboes grade (B).
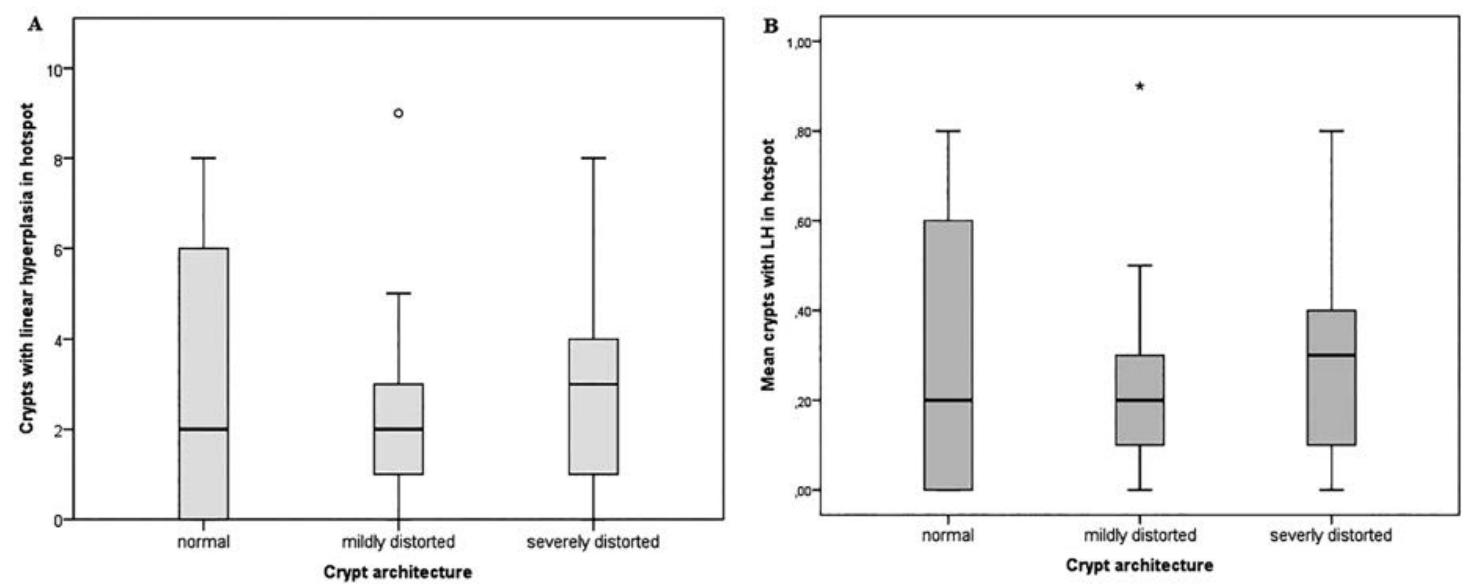

Figure 6. Mean neuroendocrine cells per crypt (A) and mean neuroendocrine linear hyperplasia in hotspot (B) in relation to crypt architecture.

histology in biopsies with inactive inflammation, which might have different traits.

On the other hand, NEC counts were generally lower in the areas with altered versus normal architecture, but not statistically significant in this sample. An interesting finding is that the level of crypt alteration seems to influence the numbers of NECs per crypt - lower counts were observed when severe distortion was present, compared to mild distortion (Figures 6A and 6B).

\section{Discussion}

In this study, we found increased NECs in ulcerative colitis patients, confirming the data in the literature $^{1-9}$. In previous studies, a threshold has been set for the definition of neuroendocrine hyperplasia at a mean of $3.2 \mathrm{NECs} / \mathrm{crypt}^{11,20}$. According to this definition, the UC patients included in our study showed NE hyperplasia, having an overall mean of 3.62 NECs/crypt. In hotspot areas, the mean number of NEC was significantly higher. Another study, that also proposed a scoring system for assessment of inflammation in UC which included NEC hyperplasia evaluated on conventional stain, defined it as ,>5 enlarged crypt epithelial cells with obvious subnuclear red granules" ${ }^{\text {"21 }}$. However, the studies showing increased NECs in ulcerative colitis show that Chromogranin A stain highlights a significantly higher number of NECs than numbers identified on hematoxylin and eosin stain. A consensus on the threshold for defining NEC hyperplasia still has to be reached. 
Nonetheless, along with using the mean number per crypt in order to describe the NEC changes, we also evaluated other descriptors for assessing the CgA stain and searched for meaningful correlations.

Thereby, we found that patients under corticosteroid treatment had significantly higher counts of maximum NECs per crypt ( $\mathrm{p}$ value 0.012 ), which frequently includes linear hyperplasia. This represents a relevant finding because the presence of this histological feature might predict the need for more sustained therapy. Though not statistically significant in this sample, patients receiving biological therapy had less crypts with linear NEC hyperplasia in the hotspot than those not on this treatment $\left(r_{\mathrm{p}}=-0.244\right.$, $\mathrm{p}=0.067)$. The lack of statistical significance could be due to the small number of patients on this type of therapy included in our study. This finding could be explained either by the fact that the patients had more severe disease activity and the biopsies included showed mostly ulceration and granulation tissue, or by the therapeutic effect of the biological agents. Further study on the histological changes in patients receiving biological therapy on a larger sample and over a longer period of time is necessary.

Another interesting finding was that the NEC counts were generally higher in biopsies with normal architecture and lower when distortion of the crypts was present, especially when the alterations were severe. This could mean that NEC hyperplasia appears after disease recurrences, paralleling the normalization of crypt architecture.

Mean NECs decreased with increasing duration of the disease. This could happen either because medication controls the disease or by other mechanisms. Another statistically significant finding was that linear hyperplasia decreased with age. This could also be related to therapy, but could also represent a normal change, since neuroendocrine cells in other organs tend to decrease with age ${ }^{22}$.

A peculiar aspect detected on several biopsies was the presence of scattered CgA positive cells within the mucosal lamina propria, usually in the lower half, and sometimes without an apparent contact to the adjacent crypts on multiple sections. In one case, a NEC micro-nest was found. It is possible that the scattered stromal NECs are precursors for the micro-nests. This association needs further research.

A limitation of this study is the fact that we could not investigate the NEC histological aspects in patients without symptoms as the follow-up of the patients by colonoscopy and subsequent histological analysis of the biopsies is vastly replaced by the use of surrogate markers, such as calprotectin ${ }^{23,24}$. Hence, we could only assess patients with histological scores or inflammation ranging from mildly to severely active inflammation activity, though patients with a Mayo score of 0 were included in the study.

\section{Conclusion}

NEC hyperplastic changes play an important role in the pathogenesis of ulcerative colitis. Further research focusing on NEC changes might have a major impact on the management of ulcerative colitis patients.

\section{Author Contributions:}

Conceptualization, A.C., and G.B.; methodology, A.C.; software, A.C; formal analysis, A.C., M.C., C.N., and F.A.; resources, A.C. and F.A.; data curation, M.C., C.N., F.A., and C.T.; writing-original draft preparation, A.C.; writing- A.C., M.C., C.N.; supervision, G.B. and M.S. All the authors have read and agreed with the final version of the article.

\section{Compliance with Ethics Requirements:}

"The authors declare no conflict of interest regarding this article"

"The authors declare that all the procedures and experiments of this study respect the ethical standards in the Helsinki Declaration of 1975, as revised in 2008(5), as well as the national law. Informed consent was obtained from all the patients included in the study"

„This research received no specific grant from any funding agency in the public, commercial, or non-for-profit sectors"

\section{Acknowledgments:}

None

\section{References}

1. Worthington JJ, Reimann F, Gribble FM. Enteroendocrine cells-sensory sentinels of the intestinal environment and orchestrators of mucosal immunity. Mucosal Immunol. 2018;11(1):3-20.

2. Yu Y, Yang W, Li Y, Cong Y. Enteroendocrine cells: sensing gut microbiota and regulating inflammatory bowel diseases. Inflamm Bowel Dis. 2020;26(1):11-20.

3. Latorre R, Sternini C, De Giorgio R, Greenwood-Van Meerveld B. Enteroendocrine cells: a review of their role in brain-gut communication. Neurogastroenterol Motil. 2015/12/21. 2016;28(5):620-30.

4. Bohórquez D V, Shahid RA, Erdmann A, et al. Neuroepithelial circuit formed by innervation of sensory enteroendocrine cells. J Clin Invest. 2015;125(2):782-6.

5. El-Salhy M, Solomon T, Hausken T, Gilja OH, Hatlebakk JG. Gastrointestinal neuroendocrine peptides/amines in inflammatory bowel Disease. World J Gastroenterol. 2017;23(28):5068-85.

6. El-Salhy M, Hausken T. The role of the neuropeptide Y (NPY) family in the pathophysiology of inflammatory bowel disease (IBD). Neuropeptides. 2016;55:137-44. 
7. Mazzawi T, Gundersen D, Hausken T, El-Salhy M. Increased chromogranin A cell density in the large intestine of patients with irritable bowel syndrome after receiving dietary guidance. Gastroenterol Res Pract. 2015;2015:34-6.

8. Massironi S, Zilli A, Cavalcoli F, Conte D, Peracchi M. Chromogranin A and other enteroendocrine markers in inflammatory bowel disease. Neuropeptides. 2016;58:127-34.

9. Arevalo F, Zurita F, Vergara G, Ramirez R, Castillo J, Monge E. Neuroendocrine cell hyperplasia in ulcerative colitis and lymphocytic colitis. Archives of Digestive Disorders. 2017;1(2):2-4.

10. Meianu C, Becheanu G, Preda C-M, et al. P047 Neuroendocrine cells densities alterations in colonic mucosa of patients with inflammatory bowel disease. J Crohn's Colitis. 2019;13(Supplement_1):S110-S110.

11. Wong M, Larson BK, Dhall D. Neuroendocrine proliferations in inflammatory bowel disease: differentiating neuroendocrine tumours from neuroendocrine cell micronests. Histopathology. 2019;74(3):415-23.

12. El-Salhy M, Danielsson $\AA$, Stenling R, Grimelius L. Colonic endocrine cells in inflammatory bowel disease. J Intern Med. 1997;242(5):413-9.

13. Giuffrida P, Vanoli A, Biletta E, et al. Increase in chromogranin A-and serotonin-positive cells in pouch mucosa of patients with ulcerative colitis undergoing proctocolectomy. Dig Liver Dis. 2018;50(11):1205-13.

14. Chojnacki C, Wiśniewska-Jarosińska M, Kulig G, Majsterek I, Reiter RJ, Chojnacki J. Evaluation of enterochromaffin cells and melatonin secretion exponents in ulcerative colitis. World J Gastroenterol. 2013;19(23):3602-7.

15. El-Salhy M, Lomholt-Beck B, Gundersen TD. High chromogranin A cell density in the colon of patients with lymphocytic colitis. Mol Med Rep. 2011;4(4):603-5.
16. Kanada S, Sugita A, Mikami T, Ohashi K, Hayashi H. Microcarcinoid arising in patients with long-standing ulcerative colitis: histological analysis. Human Pathology. 2017;64:28-36.

17. Marchal-Bressenot A, Salleron J, Boulagnon-Rombi C, et al. Development and validation of the Nancy histological index for UC. Gut. 2017;66(1):43-9.

18. Geboes K, Riddell R, Ost A, Jensfelt B, Persson T, Löfberg R. A reproducible grading scale for histological assessment of inflammation in ulcerative colitis. Gut. 2000;47(3):404-9.

19. Bankhead P, Loughrey MB, Fernández JA, et al. QuPath: Open source software for digital pathology image analysis. Sci Rep. 2017;7(1):16878.

20. Nascimbeni R, Villanacci V, Di Fabio F, Gavazzi E, Fellegara G, Rindi G. Solitary microcarcinoid of the rectal stump in ulcerative colitis. Neuroendocrinology. 2005;81(6):400-4.

21. Naini BV, Cortina G. A histopathologic scoring system as a tool for standardized reporting of chronic (ileo)colitis and independent risk assessment for inflammatory bowel disease. Hum Pathol. 2012;43(12):2187-96.

22. DeLellis RA, Dayal Y. Markers of neuroendocrine cells. In: Mills SE, editor. Histology for Pathologists. 4th ed. Wolters Kluwer Lippincott Eilliams \& Wilkins; 2017, p. 1262.

23. Magro F, Lopes S, Coelho R, et al. Accuracy of faecal calprotectin and neutrophil gelatinase B-associated lipocalin in evaluating subclinical inflammation in ulcerative colitis-the ACERTIVE study. J Crohn's Colitis. 2017;11(4):435-44.

24. Ginghina $O$, Negrei C, Hudita A, et al. In vitro impact of some natural compounds on HT-29 colorectal adenocarcinoma cells. Farmacia. 2017;65(6):947-953. 